\title{
POLLUTION HETEROGENEITY-BASED ANALYSIS ON INFLUENCES OF RESEARCH AND DEVELOPMENT (R\&D) SUBSIDY ON ENERGY CONSUMPTION AND ENERGY STRUCTURE IN THE CHINESE INDUSTRIAL SECTOR
}

\author{
HUANG, $\mathrm{H}$. \\ Department of Chinese Law and Economics Management, Shengli College, China University of \\ Petroleum, Dongying 257061, China \\ (e-mail: 13805460321@139.com; phone: +86-138-0546-0321) \\ (Received $5^{\text {th }}$ Feb 2019; accepted $6^{\text {th }}$ Mar 2019)
}

\begin{abstract}
Based on the data on the Chinese industrial sector in 2009 2015, this paper empirically analyses the effect of research and development $(R \& D)$ subsidy on energy consumption and energy structure of the industry in China. The research results show that the R\&D subsidy slowed down the growth of the total energy consumption in the Chinese industrial sector and promoted the optimization of the energy structure in the short term. On this basis, the author investigated how these impacts varied within so called pollution departments. The investigation reveals a significant impact of R\&D subsidy in high-pollution departments: the subsidy greatly suppressed the energy consumption and optimized the energy structure of these departments; for low-pollution departments, the R\&D subsidy had no major impacts on energy consumption or energy structure.
\end{abstract}

Keywords: $R \& D$ subsidy, compensation effect, price effect, scale effect, regression analysis, heterogeneity analysis

\section{Introduction}

Over the years, China has consumed a large amount of basic resources, especially energy, for industrial development. With abundant coal and limited oil, China's industrial development relies on the direct use of coal and the consumption of secondary energy (e.g. thermal power) produced from coal. The coal-based energy structure has brought serious pollution. In his report at the $19^{\text {th }}$ National Congress of the Communist Party of China (CPC), Xi (2017) said, "To ensure harmony between humanity and nature, we must realize that lucid waters and lush mountains are invaluable assets and act on this understanding, implement our fundamental national policy of conserving resources and protecting the environment." Under his call, the government, researchers and the public began to focus on industrial development and environmental issues, striving to optimize consumption and energy structure, and achieve sustainable development (Shang and Zhu, 2018).

In addition to promoting stable economic growth, technological progress can reduce pollution and facilitate energy conservation and emission reduction in the industry. The R\&D activities have significant public attributes and positive externalities. By subsidising the research and development (R\&D) of manufacturers, the government can correct market failures in $R \& D$ activities, lower the $R \& D$ risks of enterprises, and improve the technical level of the industry as a whole (Xu et al., 2014). Despite the numerous studies on the relationship between R\&D subsidy and technological innovation (Wu and Liu, 2014; Xiao and Lin, 2014; Zhao and Yao, 2017), there are still two unresolved questioned: Is it possible for the government to simulate technological progress of producers through $\mathrm{R} \& \mathrm{D}$ subsidy, thus improving the overall energy 
conservation of the industry? Are there any differences in the energy-saving effects of government R\&D subsidy for industries at different levels of pollution or technology? Answering these two questions will help China formulate future industrial subsidy policies, transform and upgrade the industry, and achieve energy conservation and emission reduction.

As mentioned before, the previous studies on $R \& D$ subsidy mainly tackle the following issues: how does R\&D subsidy impact enterprise R\&D inputs (Busom, 2000; Jiang and Huang, 2010), whether R\&D subsidy affects innovation efficiency (Lv and Sun, 2014) and what is the crowding-out effect of R\&D subsides (Lach, 2002; Wallsten, 2000). However, there is little report on the influence of $R \& D$ subsides over socioeconomic development or environmental improvement (Song, 2018). Particular attention should be paid to the positive externalities of subsidy, a common financial remedy to market failures, on a social basis. Therefore, this paper intends to expand the scope of existing research into the relationship between R\&D subsidy and innovation.

Moreover, China is now faced with serious resource misallocation due to the legacy of the planned economic system. The problem is particularly severe in the field of science and technology (Han and Zheng, 2014). Against this backdrop, some inefficient industries waste R\&D subsidy in blind expansion of low-efficiency production, rather than develop and upgrade technology. The resulting pollution and excess capacity hinder the industrial transformation and upgrading and harm the environmental protection in China. As a result, this research aims to help the government design and develop more flexible and effective R\&D subsidy policies.

Overall, this paper attempts to disclose the effects of $R \& D$ subsidy on energy consumption and energy structure, and discover the far-reaching impact of R\&D subsidy on China's environment, laying a valuable basis for the pursuit of an ecological civilization.

\section{Materials and method}

\section{Theoretical analysis}

The R\&D subsidy affects energy consumption and energy structure through three channels, namely, the compensation effect, the price effect and the scale effect. Below is a detailed description of each channel.

\section{Compensation effect}

The public attributes of producers' technical R\&D activities often result in high cost, high risk and a long-term investment (Danneels and Kleinschmidtb, 2010). Owing to the spill-over of producers' R\&D activities, the expected returns are reduced to a level far below the generated social benefits. Hence, the producers are deprived of the resources for further R\&D activities (Cohen and Levinthal, 2015). The government's R\&D subsidy partially offsets the producers' loss of expected returns caused by technology spill-over, and compensates or even enhances the expected returns of the producers' R\&D activities. This brings positive signals and stimuli to producers' R\&D behaviour. Meanwhile, the government's R\&D subsidy partially lowers the risks generated by $R \& D$ activities, suppresses the negative impact of uncertain $R \& D$ outcome on the expected returns, and arouses producers' interest in and continuous inputs to R\&D (Lichtenberg, 2001). To sum up, the government's R\&D subsidy can 
bolster the R\&D inputs of the producers, and promote the technological progress and innovation ability of the producers and whole industry. This, in turn, encourages the energy conservation and emission reduction in the whole industry, leading to lower energy consumption and more efficient energy use.

\section{Price effect}

The price effect is demonstrated in the indirect impacts on the efficiency and price of energy production. On climate change policies, Sinn (2008) discovered the "green paradox": the policies against climate change will lead to the growth in energy consumption and the accumulation of greenhouse gases. Sinn presented the following explanation to the transmission mechanism of "green paradox": all industries will enjoy more efficient production and better technologies thanks to technological progress; in the energy industry, the results of technological progress are demonstrated as improved efficiency of energy production and the reduced energy price; as the price drop reduces production costs, producers tend to consume more energy and release more greenhouse gases. Maria et al. (2014) analysed the coal prices in the US from 1986 to 1994, noting that the reduction of energy price caused by technological progress has increased energy consumption. Thus, the R\&D subsidy, through the technological progress in the energy industry, can lower the energy supply price, and in turn affect the total energy consumption in other industries.

\section{Scale effect}

The scale effect of government R\&D subsidy mainly comes from the crowding-out effect, which propels the expansion of production scale. When the government subsidises producers' R\&D activities, the government funds will displace the producers' R\&D inputs (Guellec and Van Pottelsberghe, 2003), allowing producers to invest the inputs to expanded reproduction. The expansion of production scale will push up energy consumption. This situation is clearly seen in high-pollution industries. In China, highpollution industries are large in scale, high indebted, and have a low the added value of products. These industries often spend spare funds on the expansion of production scale, aiming to reduce unit cost of products and realize returns to scale. To some extent, this explains the expansion and overcapacity of some traditional industries in China, despite the continuous growth in R\&D subsidy in recent years.

\section{Samples and data sources}

The relevant data on R\&D subsidy and energy consumption of the energy industry from 2009 to 2015 were adopted for this study. The data in 2009 and 2010 were adjusted according to the latest classification method for industrial sectors issued by China in 2011. For instance, the plastic products industry and rubber products industry were merged into the rubber and plastic products industry, while the automobile manufacturing industry was combined with the manufacturing industries for railway, shipping, aerospace and other transportation equipment into the transportation equipment manufacturing industry. After the adjustment, the data were divided into 36 industrial sectors according to the 2011 industrial sector classification method, excluding those on the other mining industry. The data on R\&D subsidy were extracted from Statistics Yearbook on Science and Technology Activities of Industrial Enterprises and China Statistical Yearbook on Science and Technology, the data on energy were 
extracted from China Energy Statistical Yearbook, and the data on other indices of industrial economy and development were extracted from China Industry Statistical Yearbook. To eliminate the interference of price on the empirical results, the relevant economic indices were deflated against the benchmark of the 2009 price.

\section{Definition and measurement of variables}

The explained variables in this paper are the total energy consumption and energy structure.

The former describes the general trend of consumption. Here, its value is expressed as standard coal converted from the data released by the statistical department. The energy structure reflects the composition of energy consumption. It is usually expressed as the ratio of the total coal-based energy consumption to the total energy consumption. The total coal-based energy consumption equals the sum of the standard coal converted from the consumption of each type of coal-based energy.

The government's R\&D subsidy is treated as an explanatory variable in this research. From the data on R\&D funds, the subsidy funds allocated by the government directly to the industries were identified manually.

A total of six control variables are adopted for this research. Among them, the industry scale was described by the proxy variable of the number of employees in the industry in the current year; the fixed assets investment was extracted directly from the data released by the statistical department; the energy price index was the ex-factory price of power fuel released by the statistical department (the value was converted against the benchmark price in 1985 to eliminate the interference of price on the empirical results); the export volume, the total revenue and the R\&D expenditure were directly extracted from the data released by the statistical department and subjected to deflation. The meanings of the above variables are given in Table 1.

Table 1. Meanings of variables

\begin{tabular}{c|c|c}
\hline Variables & Description & Unit \\
\hline $\begin{array}{c}\text { Energy } \\
\text { consumption }\end{array}$ & The amount of energy that one industrial sector consume in 1 year & $\begin{array}{c}104 \text { tons of } \\
\text { standard coal }\end{array}$ \\
\hline Energy structure & Ratio of coal-based energy to total energy & $\%$ \\
\hline R\&D subsidy & Funds that the government allocates to enterprise for R\&D & 104 Yuan \\
\hline Size & Size of one industrial sector & 104 persons \\
\hline $\begin{array}{c}\text { Fixed asset } \\
\text { investment }\end{array}$ & $\begin{array}{c}\text { Expenses for the construction and purchase, such as capital } \\
\text { construction, renovation and major repairs, etc }\end{array}$ & 109 Yuan \\
\hline $\begin{array}{c}\text { Energy prices } \\
\text { index }\end{array}$ & An index of the price of energy purchased by producers & \\
\hline Export & The total revenue that a producer sell its products abroad & 109 Yuan \\
\hline Revenue & The total revenue that a producer sell its product or service in 1 year & 109 Yuan \\
\hline $\begin{array}{c}\text { R\&D expenditure } \\
\text { Retal expenditure invested by producers for scientific research and } \\
\text { development activities }\end{array}$ & $\begin{array}{c}\text { Total } \\
\text { Ruan }\end{array}$ \\
\hline
\end{tabular}

\section{Construction of regression equations}

The following econometric equations were established to test the impact of government R\&D subsidy on energy consumption and energy structure. In Equations 1 
and 2, the current year data on $R \& D$ subsidy are taken as the explanatory variables, aiming to measure the short-term impact. In Equations 3 and 4, the subsequent year data on $R \& D$ subsidy are taken as the explanatory variables, aiming to measure the longterm impact.

$$
\begin{aligned}
& E C_{\mathrm{it}}=\alpha_{0}+\alpha_{1} \operatorname{Subs}_{\mathrm{t}}+\alpha_{2} \operatorname{Size}_{\mathrm{it}}+\alpha_{3} F I_{\mathrm{it}}+\alpha_{4} P_{\mathrm{it}}+\alpha_{5} \operatorname{Exp}_{\mathrm{it}}+\alpha_{6} R_{\mathrm{it}}+\alpha_{7} R D_{\mathrm{it}}+\varepsilon_{i t} \text { (Eq.1) } \\
& E S_{\mathrm{it}}=\alpha_{0}+\alpha_{1} \operatorname{Subs}_{\mathrm{t}}+\alpha_{2} \operatorname{Size}_{\mathrm{it}}+\alpha_{3} F I_{\mathrm{it}}+\alpha_{4} P_{\mathrm{it}}+\alpha_{5} \operatorname{Exp}_{\mathrm{it}}+\alpha_{6} R_{\mathrm{it}}+\alpha_{7} R D_{\mathrm{it}}+\varepsilon_{i t} \text { (Eq.2) } \\
& E C_{\mathrm{it}}=\beta_{0}+\beta_{1} \operatorname{Subs}_{\mathrm{it}-1}+\beta_{2} \operatorname{Size}_{\mathrm{it}}+\beta_{3} F I_{\mathrm{it}}+\beta_{4} P_{\mathrm{it}}+\beta_{5} \operatorname{Exp}_{\mathrm{it}}+\beta_{6} R_{\mathrm{it}}+\beta_{7} R D_{\mathrm{it}}+\varepsilon_{i t} \text { (Eq.3) } \\
& E S_{\mathrm{it}}=\beta_{0}+\beta_{1} \operatorname{Subs}_{\mathrm{it}-1}+\beta_{2} \operatorname{Size}_{\mathrm{it}}+\beta_{3} F I_{\mathrm{it}}+\beta_{4} P_{\mathrm{it}}+\beta_{5} \operatorname{Exp}_{\mathrm{it}}+\beta_{6} R_{\mathrm{it}}+\beta_{7} R D_{\mathrm{it}}+\varepsilon_{i t} \text { (Eq.4) }
\end{aligned}
$$

where EC is the total energy consumption; ES is the energy structure; Subs is the R\&D subsidy; Size is the industrial scale; FI is the total fixed asset investment; $\mathrm{P}$ is the energy price index; Exp is the export volume; $\mathrm{R}$ is the total revenue; $\mathrm{RD}$ is the $\mathrm{R} \& \mathrm{D}$ expenditure; the subscript $i$ refers to the industry; the subscript $t$ refers to the year.

\section{Results}

\section{Statistical description}

According to the statistical description of data in Table 2, the energy consumption ranged between 69,543.27 and 110.10, revealing a huge gap in energy consumption among different industries; the minimum energy structure stood at 0.02 only, a mirror of the intensive and efficient use of non-coal-based energy in some industries, which explains the massive gap in total energy consumption among different industries; the industries also differed greatly in the amount of R\&D subsidy, indicating the sharp difference in $R \& D$ level and technical level among the industries.

Table 2. Statistical description of data

\begin{tabular}{c|c|c|c|c|c|c}
\hline Variables & Observations & Mean & Std. dev & Min & Max & Unit \\
\hline Energy consumption & 252 & 5085.74 & 11270.81 & 110.10 & 69543.27 & $10^{4}$ tons of standard coal \\
Energy structure & 252 & 0.28 & 0.19 & 0.02 & 0.81 & $\%$ \\
R\&D subsidy & 252 & 110326.80 & 227060.60 & 194 & 1790916 & $10^{4}$ Yuan \\
Size & 252 & 262.92 & 208.07 & 18.09 & 909.26 & $10^{4}$ persons \\
Fixed asset investment & 252 & 4206.14 & 3878.60 & 208.38 & 20260.41 & $10^{9}$ Yuan \\
Energy prices index & 252 & 99.94 & 9.64 & 88.70 & 116.30 & \\
Export & 252 & 2834.67 & 6665.19 & 0.09 & 46165.14 & $10^{9}$ Yuan \\
Revenue & 252 & 24742.62 & 22280.99 & 966.33 & 91606.58 & $10^{9}$ Yuan \\
R\&D expenditure & 252 & 1899258 & 2803182 & 1457 & $1.61 \mathrm{e}+07$ & $10^{4}$ Yuan \\
\hline
\end{tabular}

\section{Variable correlation analysis}

Table 3 records the results of correlation analysis on the variables. The analysis focuses on the correlations between government R\&D subsidy and the two explained variables. As shown in Table 3, the R\&D subsidy is positively correlated with the total 
energy consumption and negatively with the energy structure. These correlations were subjected to empirical analysis in the next section.

Table 3. Variable correlation analysis

\begin{tabular}{c|c|c|c|c|c|c|c|c|c}
\hline Variables & & & & & & & & & \\
\hline Energy consumption & 1.0000 & & & & & & & & \\
Energy structure & 0.0767 & 1.0000 & & & & & & & \\
R\&D subsidy & 0.0025 & -0.1965 & 1.0000 & & & & & & \\
Size & 0.2531 & 0.1177 & 0.5814 & 1.0000 & & & & & \\
Fixed asset investment & 0.3247 & 0.0537 & 0.4928 & 0.6255 & 1.0000 & & & & \\
Energy prices index & -0.0274 & -0.0212 & -0.0439 & -0.0007 & -0.1423 & 1.0000 & & & \\
Export & -0.0316 & -0.2303 & 0.5228 & 0.6508 & 0.2235 & -0.0082 & 1.0000 & & \\
Revenue & 0.5304 & -0.0440 & 0.6279 & 0.7922 & 0.7959 & -0.0636 & 0.5094 & 1.0000 & \\
R\&D expenditure & 0.2753 & -0.2126 & 0.8404 & 0.7397 & 0.5883 & -0.0928 & 0.7121 & 0.8256 & 1.0000 \\
\hline
\end{tabular}

\section{Analysis of empirical results}

Before the regression analysis, the collinearity between the variables was tested. The results show no sign of collinearity. Next, the correlations between R\&D subsidy and the two explained variables were tested and analysed on Stata 14.

Table 4 shows the effect of R\&D subsidy on the total energy consumption. Under the control of time trend, Models (1) and (2) are a random effect model and a fixed effect model on the short-term effect, respectively. The results of the random effect model were adopted according to the Durbin-Wu-Hausman test. The results of Model (1) show that, in the short term, the R\&D subsidy had a significant negative correlation with the total energy consumption. This means the energy consumption will decline with the increase in the $R \& D$ subsidy. The results also prove that the total energy consumption is positively correlated with the industrial scale, the total revenue and the R\&D expenditure, but negatively with the fixed asset investment and the export volume.

Under the control of time trend, Models (3) and (4) are a random effect model and a fixed effect model on the long-term effect, respectively. The results of the fixed effect model were adopted according to the Durbin-Wu-Hausman test. It can be seen that the growth in total energy consumption was significantly suppressed with the increase in R\&D subsidy.

Table 5 describes the effect of R\&D subsidy on the energy structure. The results of Model (5) were verified by Durbin-Wu-Hausman test. According to these results, the R\&D subsidy improved the energy structure and reduced the ratio of coal-based energy in the energy consumption of production in the short term. In particular, the energy price index significantly boosted the improvement of the energy structure. Hence, the R\&D subsidy can elevate the efficiency of the energy industry to a certain extent and thus reduce the price of energy supply and service. In the long run, R\&D subsidy did not exert a significant impact to improvement of the energy structure. According to the results of Durbin-Wu-Hausman test, the R\&D subsidy in the subsequent year had no major impact on the improvement of the energy structure.

In summary, the above results indicate that $R \& D$ subsidy alleviated the growth trend of the total energy consumption and improved the energy structure in the short term. 
Table 4. Effect of $R \& D$ subsidy on the total energy consumption

\begin{tabular}{c|c|c|c|c}
\hline Energy consumption & Model (1) & Model (2) & Model (3) & Model (4) \\
\hline \multirow{2}{*}{ Subsidy } & $-0.0173^{* * *}$ & $-0.0166^{* * *}$ & & \\
& $(0.00274)$ & $(0.00277)$ & & \\
\hline \multirow{2}{*}{ Subsidy (t-1) } & & & $-0.0185^{* * *}$ & $-0.0167^{* * *}$ \\
& & & $(0.00408)$ & $(0.00421)$ \\
\hline \multirow{2}{*}{ Size } & $11.27^{* *}$ & $11.63^{* *}$ & 8.905 & $12.08^{*}$ \\
& $(4.833)$ & $(5.629)$ & $(5.875)$ & $(7.013)$ \\
\hline \multirow{2}{*}{ Fixed asset investment } & $-0.586^{* * *}$ & $-0.488^{* * *}$ & $-0.486^{* * *}$ & $-0.345^{*}$ \\
& $(0.140)$ & $(0.141)$ & $(0.176)$ & $(0.182)$ \\
\hline \multirow{2}{*}{ Energy price index } & -18.19 & -17.08 & -10.04 & -16.58 \\
& $(12.27)$ & $(12.02)$ & $(19.28)$ & $(19.18)$ \\
\hline \multirow{2}{*}{ Export } & $-0.684^{* * *}$ & $-0.641^{* * * *}$ & $-0.674^{* * * *}$ & $-0.631^{* * * *}$ \\
& $(0.130)$ & $(0.142)$ & $(0.169)$ & $(0.206)$ \\
\hline \multirow{2}{*}{ Revenue } & $0.238^{* * *}$ & $0.202^{* * *}$ & $0.284^{* * *}$ & $0.209^{* * *}$ \\
& $(0.0425)$ & $(0.0433)$ & $(0.0592)$ & $(0.0636)$ \\
\hline \multirow{2}{*}{ R\&D expenditure } & $0.00126^{* * *}$ & $0.00125^{* * *}$ & $0.00103^{* *}$ & $0.00103^{* *}$ \\
& $(0.000317)$ & $(0.000320)$ & $(0.000405)$ & $(0.000418)$ \\
\hline \multirow{2}{*}{ Cons_ } & 1,974 & 2,063 & 404.3 & 1,245 \\
& $(1,953)$ & $(1,624)$ & $(2,681)$ & $(2,556)$ \\
\hline \multirow{2}{*}{ Wald chia2/F } & 181.72 & 21.57 & 120.26 & 12.10 \\
& $(0.0000)$ & $(0.0000)$ & $(0.0000)$ & $(0.0000)$ \\
\hline Time & Yes & Yes & Yes & Yes \\
\hline Hausman test & $1.02[0.7959]$ & & & $9.56[0.0888]$ \\
\hline Observations & 252 & 252 & 216 & 216 \\
\hline $\mathrm{R}^{2}$ & & 0.419 & & 0.329 \\
\hline & & &
\end{tabular}

Significance: $* * * p<0.01,{ }^{* *} \mathrm{p}<0.05,{ }^{*} \mathrm{p}<0.1$

\section{Pollution heterogeneity-based analysis}

After examining the impact of R\&D subsidy on energy consumption and the energy structure of the entire industrial sector in China, this paper further explores whether the impact differs with the pollution levels. According to the Guide for Environmental Information Disclosure of Listed Companies issued by the Chinese Ministry of Ecology and Environment, the 36 samples were divided into high-pollution departments (16) and low-pollution departments (20), and subjected to analysis separately. The results are listed in Tables 6 and 7.

In Table 6, Models (9) and (10) are about the short- and long-term impacts of R\&D subsidy on energy consumption in different pollution industries, respectively. For highpollution departments, the R\&D subsidy exerted a significant negative impact on energy consumption in both short- and long-term, indicating that the subsidy can indeed curb the growth of energy consumption in high -pollution departments. As shown in Models (11) and (12), the R\&D subsidy had no significant effect on energy consumption of low-pollution departments. In high-pollution industries, the R\&D subsidy can promote the upgrading of industrial technology, and thus bolster the implementation of energy 
conservation and emission reduction. The bolstering effect is particularly obvious in energy-sensitive areas like high-pollution departments. By contrast, low-pollution departments are not sensitive to energy demand, for they emphasize on with the improvement of product technology over the change of production technology.

Table 5. Effect of $R \& D$ subsidy on energy structure

\begin{tabular}{|c|c|c|c|c|}
\hline Energy structure & Model (5) & Model (1) & Model (7) & Model (8) \\
\hline Subsidy & $\begin{array}{c}-1.94 \mathrm{e}-07 * * \\
(7.60 \mathrm{e}-08)\end{array}$ & $\begin{array}{c}-1.95 \mathrm{e}-07 * * \\
(7.87 \mathrm{e}-08)\end{array}$ & & \\
\hline Subsidy (t-1) & & & $\begin{array}{l}-6.11 \mathrm{e}-08 \\
(1.09 \mathrm{e}-07) \\
\end{array}$ & $\begin{array}{l}-5.01 \mathrm{e}-08 \\
(1.16 \mathrm{e}-07) \\
\end{array}$ \\
\hline Size & $\begin{array}{c}0.000764 * * * \\
(0.000128)\end{array}$ & $\begin{array}{c}0.000924 * * * \\
(0.000160)\end{array}$ & $\begin{array}{c}0.000602 * * * \\
(0.000149)\end{array}$ & $\begin{array}{c}0.000724 * * * \\
(0.000192)\end{array}$ \\
\hline Fixed asset investment & $\begin{array}{c}-1.39 \mathrm{e}-05 * * * \\
(3.88 \mathrm{e}-06) \\
\end{array}$ & $\begin{array}{c}-1.57 \mathrm{e}-05^{* * *} \\
(4.01 \mathrm{e}-06)\end{array}$ & $\begin{array}{c}-1.15 \mathrm{e}-05^{* *} \\
(4.70 \mathrm{e}-06)\end{array}$ & $\begin{array}{c}-1.35 \mathrm{e}-05 * * * \\
(4.98 \mathrm{e}-06)\end{array}$ \\
\hline Energy price index & $\begin{array}{c}-0.00112 * * * \\
(0.000345) \\
\end{array}$ & $\begin{array}{c}-0.00121 * * * \\
(0.000341)\end{array}$ & $\begin{array}{l}-0.000630 \\
(0.000524) \\
\end{array}$ & $\begin{array}{l}-0.000453 \\
(0.000526) \\
\end{array}$ \\
\hline Export & $\begin{array}{c}-9.52 \mathrm{e}-06 * * * \\
(3.50 \mathrm{e}-06)\end{array}$ & $\begin{array}{l}-7.04 \mathrm{e}-06^{*} \\
(4.02 \mathrm{e}-06)\end{array}$ & $\begin{array}{c}-8.49 \mathrm{e}-06 * * \\
(4.27 \mathrm{e}-06) \\
\end{array}$ & $\begin{array}{l}-7.08 \mathrm{e}-07 \\
(5.66 \mathrm{e}-06)\end{array}$ \\
\hline Revenue & $\begin{array}{l}-4.24 \mathrm{e}-07 \\
(1.18 \mathrm{e}-06) \\
\end{array}$ & $\begin{array}{l}-3.00 \mathrm{e}-07 \\
(1.23 \mathrm{e}-06)\end{array}$ & $\begin{array}{c}1.10 \mathrm{e}-06 \\
(1.55 \mathrm{e}-06)\end{array}$ & $\begin{array}{c}1.79 \mathrm{e}-06 \\
(1.74 \mathrm{e}-06)\end{array}$ \\
\hline $\mathrm{R} \& \mathrm{D}$ expenditure & $\begin{array}{c}1.43 \mathrm{e}-08 \\
(8.81 \mathrm{e}-09)\end{array}$ & $\begin{array}{c}1.37 \mathrm{e}-08 \\
(9.07 \mathrm{e}-09)\end{array}$ & $\begin{array}{l}-9.69 \mathrm{e}-10 \\
(1.08 \mathrm{e}-08)\end{array}$ & $\begin{array}{l}-3.84 \mathrm{e}-09 \\
(1.15 \mathrm{e}-08)\end{array}$ \\
\hline Cons_ & $\begin{array}{c}0.278 * * * \\
(0.0505)\end{array}$ & $\begin{array}{c}0.244 * * * \\
(0.0461)\end{array}$ & $\begin{array}{c}0.230 * * * \\
(0.0688) \\
\end{array}$ & $\begin{array}{l}0.153 * * \\
(0.0701) \\
\end{array}$ \\
\hline Wald chia2/F & $\begin{array}{c}13.52 \\
(0.0000) \\
\end{array}$ & $\begin{array}{c}11.29 \\
(0.0000) \\
\end{array}$ & $\begin{array}{c}30.54 \\
(0.0001) \\
\end{array}$ & $\begin{array}{c}5.01 \\
(0.0000) \\
\end{array}$ \\
\hline Time & Yes & Yes & Yes & Yes \\
\hline Hausman test & $7.65[0.1051]$ & & & $12.95[0.0239]$ \\
\hline Observations & 252 & 252 & 216 & 216 \\
\hline $\mathrm{R}^{2}$ & & 0.274 & & 0.169 \\
\hline
\end{tabular}

Significance: $* * * p<0.01, * * \mathrm{p}<0.05, * \mathrm{p}<0.1$

Table 7 illustrates the impacts of R\&D subsidy on the energy structure in different pollution departments. As shown in models (13) and (14), the R\&D subsidy exerted a significant negative impact on energy structure in both short- and long-term for highpollution departments, indicating that the subsidy reduces the use of coal-based energy in these departments; for low-pollution departments, the R\&D subsidy had no significant short- or long-term effect on energy consumption. This situation can be attributed to two factors. First, the R\&D subsidy promotes the industrial transformation and upgrading, especially in high-pollution industries. These departments are less dependent on traditional coal-based energy, due to the improvement in production flow and processes. The consumption of coal-based energy is further reduced by the increase in total factor productivity induced by the $R \& D$ subsidy. Second, the R\&D subsidy drives the development of new energy production, leading to lower prices of energy 
supply and energy service. Thus, the traditional departments could use new energies at a much lower cost, which indirectly optimizes the energy structure of high-pollution departments.

Table 6. Impact of $R \& D$ subsidy on energy consumption of each pollution industry

\begin{tabular}{|c|c|c|c|c|}
\hline Energy consumption & Model (9) & Model (10) & Model (11) & Model (12) \\
\hline Subsidy & $\begin{array}{c}-0.0458 * * * \\
(0.0103)\end{array}$ & & $\begin{array}{c}3.93 \mathrm{e}-06 \\
(0.000243)\end{array}$ & \\
\hline Subsidy (t-1) & & $\begin{array}{c}-0.0356 * * * \\
(0.0126)\end{array}$ & & $\begin{array}{c}-6.11 \mathrm{e}-05 \\
(0.000329)\end{array}$ \\
\hline Size & $\begin{array}{c}28.88 * * * \\
(7.791)\end{array}$ & $\begin{array}{l}33.24 * * \\
(12.87)\end{array}$ & $\begin{array}{c}0.670 \\
(0.530)\end{array}$ & $\begin{array}{l}-0.160 \\
(0.615)\end{array}$ \\
\hline Fixed asset investment & $\begin{array}{l}-0.459 * \\
(0.237)\end{array}$ & $\begin{array}{l}-0.385 \\
(0.300)\end{array}$ & $\begin{array}{c}0.0101 \\
(0.0169)\end{array}$ & $\begin{array}{c}0.0227 \\
(0.0196)\end{array}$ \\
\hline Energy price index & $\begin{array}{l}-27.66 \\
(23.60)\end{array}$ & $\begin{array}{l}-37.55 \\
(34.30)\end{array}$ & $\begin{array}{l}-1.968 \\
(1.250)\end{array}$ & $\begin{array}{c}1.858 \\
(2.014)\end{array}$ \\
\hline Export & $\begin{array}{l}-0.566 \\
(0.873)\end{array}$ & $\begin{array}{l}0.0922 \\
(1.370)\end{array}$ & $\begin{array}{l}-0.0147 \\
(0.0109)\end{array}$ & $\begin{array}{l}-0.00929 \\
(0.0125)\end{array}$ \\
\hline Revenue & $\begin{array}{c}0.143^{*} \\
(0.0760)\end{array}$ & $\begin{array}{c}0.117 \\
(0.114)\end{array}$ & $\begin{array}{l}0.0346 * * * \\
(0.00571)\end{array}$ & $\begin{array}{l}0.0474 * * * \\
(0.00685)\end{array}$ \\
\hline R\&D expenditure & $\begin{array}{c}0.00336^{* * * *} \\
(0.000699)\end{array}$ & $\begin{array}{l}0.00326 * * * \\
(0.000968)\end{array}$ & $\begin{array}{c}-0.000138 * * * \\
(3.09 \mathrm{e}-05)\end{array}$ & $\begin{array}{c}-0.000183 * * * \\
(3.57 \mathrm{e}-05)\end{array}$ \\
\hline Cons_ & $\begin{array}{c}1,765 \\
(3,314)\end{array}$ & $\begin{array}{c}345.8 \\
(4,393)\end{array}$ & $\begin{array}{c}530.5 * * * \\
(171.8)\end{array}$ & $\begin{array}{c}95.81 \\
(249.2)\end{array}$ \\
\hline Wald chia2/F & $\begin{array}{c}197.50 \\
(0.0000)\end{array}$ & $\begin{array}{c}14.53 \\
(0.0000)\end{array}$ & $\begin{array}{c}211.42 \\
(0.0000)\end{array}$ & $\begin{array}{c}194.74 \\
(0.0000)\end{array}$ \\
\hline Time & Yes & Yes & Yes & Yes \\
\hline Hausman test & $6.48[0.1659]$ & $10.85[0.0543]$ & $2.71[0.4378]$ & $4.30[0.2308]$ \\
\hline Observations & 112 & 96 & 140 & 120 \\
\hline \multirow[t]{2}{*}{$\mathrm{R}^{2}$} & 0.680 & 0.582 & 0.592 & 0.604 \\
\hline & $\begin{array}{l}\text { High polluting } \\
\text { sectors }\end{array}$ & $\begin{array}{l}\text { High polluting } \\
\text { sectors }\end{array}$ & $\begin{array}{l}\text { Low polluting } \\
\text { sectors }\end{array}$ & $\begin{array}{c}\text { Low polluting } \\
\text { sectors }\end{array}$ \\
\hline
\end{tabular}

Significance: $* * * p<0.01, * * p<0.05, * p<0.1$

\section{Discussion}

In China, the R\&D subsidy has a direct and targeted effect on the total energy consumption. For one thing, the Chinese government wants to promote industrial transformation and upgrading through subsidising the R\&D activities of enterprises in an industry. The subsidised enterprises are required to invest the subsidy to $R \& D$ activities. In this way, the R\&D subsidy pushes up industrial R\&D expenditure, and in turn the overall technical level and productivity of the industry. This is conducive to the energy conservation and emission reduction in the short- and long-term, and the efficiency of energy use, which slows down the growth of energy demand in China's industrial sector. For another, the R\&D subsidy favours high and new technology enterprises. Since these enterprises are more likely to receive a huge amount of R\&D 
subsidy, the high and new industries will expand at the cost of the traditional industries. The spill-over effect of these industries will spread new technologies across different sectors, slowing down the growth of energy demand in China's industrial sector.

Table 7. Impact of $R \& D$ subsidy on energy structure of each pollution industry

\begin{tabular}{|c|c|c|c|c|}
\hline Energy structure & Model (13) & Model (14) & Model (15) & Model (16) \\
\hline Subsidy & $\begin{array}{c}-1.34 \mathrm{e}-07 * * \\
(2.28 \mathrm{e}-07)\end{array}$ & & $\begin{array}{c}2.02 \mathrm{e}-07 \\
(9.87 \mathrm{e}-08)\end{array}$ & \\
\hline Subsidy (t-1) & & $\begin{array}{c}-5.69 \mathrm{e}-07 * * \\
(2.64 \mathrm{e}-07)\end{array}$ & & $\begin{array}{l}-1.12 \mathrm{e}-07 \\
(1.39 \mathrm{e}-07)\end{array}$ \\
\hline Size & $\begin{array}{c}0.000652 * * * \\
(0.000203)\end{array}$ & $\begin{array}{c}0.000281 \\
(0.000269)\end{array}$ & $\begin{array}{c}0.00142 * * * \\
(0.000307)\end{array}$ & $\begin{array}{c}0.00126 * * * \\
(0.000362) \\
\end{array}$ \\
\hline Fixed asset investment & $\begin{array}{c}-1.80 \mathrm{e}-05 * * * \\
(5.40 \mathrm{e}-06)\end{array}$ & $\begin{array}{c}-1.76 \mathrm{e}-05 * * * \\
(6.28 \mathrm{e}-06) \\
\end{array}$ & $\begin{array}{l}-9.84 \mathrm{e}-06 \\
(6.74 \mathrm{e}-06) \\
\end{array}$ & $\begin{array}{l}-4.22 \mathrm{e}-06 \\
(8.05 \mathrm{e}-06)\end{array}$ \\
\hline Energy price index & $\begin{array}{c}-0.00145^{* * *} \\
(0.000517)\end{array}$ & $\begin{array}{l}-0.000364 \\
(0.000717) \\
\end{array}$ & $\begin{array}{l}-0.00101 * * \\
(0.000471) \\
\end{array}$ & $\begin{array}{c}2.24 \mathrm{e}-05 \\
(0.000785) \\
\end{array}$ \\
\hline Export & $\begin{array}{c}4.12 \mathrm{e}-06 \\
(2.12 \mathrm{e}-05)\end{array}$ & $\begin{array}{c}3.63 \mathrm{e}-05 \\
(2.87 \mathrm{e}-05) \\
\end{array}$ & $\begin{array}{l}-8.78 \mathrm{e}-06^{*} \\
(5.13 \mathrm{e}-06)\end{array}$ & $\begin{array}{l}-6.66 e-07 \\
(6.64 e-06) \\
\end{array}$ \\
\hline Revenue & $\begin{array}{l}-6.41 \mathrm{e}-07 \\
(1.72 \mathrm{e}-06)\end{array}$ & $\begin{array}{c}1.73 \mathrm{e}-06 \\
(2.39 \mathrm{e}-06)\end{array}$ & $\begin{array}{l}-3.27 \mathrm{e}-06 \\
(2.50 \mathrm{e}-06) \\
\end{array}$ & $\begin{array}{l}-2.07 e-06 \\
(3.20 \mathrm{e}-06)\end{array}$ \\
\hline $\mathrm{R} \& \mathrm{D}$ expenditure & $\begin{array}{c}1.64 \mathrm{e}-08 \\
(1.57 \mathrm{e}-08)\end{array}$ & $\begin{array}{l}-1.05 \mathrm{e}-08 \\
(2.03 \mathrm{e}-08)\end{array}$ & $\begin{array}{c}1.49 \mathrm{e}-08 \\
(1.25 \mathrm{e}-08)\end{array}$ & $\begin{array}{c}8.87 \mathrm{e}-10 \\
(1.52 \mathrm{e}-08)\end{array}$ \\
\hline Cons_ & $\begin{array}{c}0.351 * * * \\
(0.0638)\end{array}$ & $\begin{array}{l}0.242 * * \\
(0.0919) \\
\end{array}$ & $\begin{array}{c}0.119 * \\
(0.0708) \\
\end{array}$ & $\begin{array}{l}-0.0156 \\
(0.109) \\
\end{array}$ \\
\hline Wald chia2/F & $\begin{array}{c}5.79 \\
(0.0000) \\
\end{array}$ & $\begin{array}{c}3.03 \\
(0.0075) \\
\end{array}$ & $\begin{array}{c}6.86 \\
(0.0000) \\
\end{array}$ & $\begin{array}{c}4.03 \\
(0.0007) \\
\end{array}$ \\
\hline Time & Yes & Yes & Yes & Yes \\
\hline Hausman test & $10.32[0.0354]$ & $13.94[0.0160]$ & $16.15[0.0028]$ & $11.46[0.0095]$ \\
\hline Observations & 112 & 96 & 140 & 120 \\
\hline \multirow[t]{2}{*}{$\mathrm{R}^{2}$} & 0.313 & 0.225 & 0.298 & 0.233 \\
\hline & $\begin{array}{c}\text { High polluting } \\
\text { sectors }\end{array}$ & $\begin{array}{c}\text { High polluting } \\
\text { sectors }\end{array}$ & $\begin{array}{l}\text { Low polluting } \\
\text { sectors }\end{array}$ & $\begin{array}{c}\text { Low polluting } \\
\text { sectors }\end{array}$ \\
\hline
\end{tabular}

Significance: $* * * p<0.01,{ }^{* *} \mathrm{p}<0.05,{ }^{*} \mathrm{p}<0.1$

The short-term optimization of the energy structure relies on the changing scale of different industries. For one thing, low-pollution and high-tech industries expand exponentially under the R\&D subsidy. These industries consume much more power and new energy than the traditional ones, which lowers the total consumption of traditional energy. For another, the traditional industries are shrinking and reorganizing. To control pollutant emissions, the Chinese government has implemented strict policies on emission control, and even shut down some small enterprises with high pollution and high energy consumption. For industrial transformation and upgrading, the government require traditional industries to merge and reorganize, in addition to issuing $R \& D$ subsidy to enterprises. To realize economies of scale and energy conservation, some traditional enterprises have implemented bankruptcy procedures and resource 
restructuring of their subsidiaries, and directly diverted the R\&D subsidy to technical progress. These measures have improved the energy structure of traditional industries to a certain extent, and affected the energy structure of the entire industrial sector in the short term.

\section{Conclusions}

This paper studies the impacts of R\&D subsidy on industrial energy consumption and the energy structure, and further analyses how these impacts vary between highand low-pollution departments. It is concluded that the R\&D subsidy has indeed slowed down the growth of energy consumption in China's industrial sector, thanks to the positively impact on technology level. According to pollution heterogeneity-based analysis, the slowdown effect is attributed to the change of energy consumption in China's high-pollution departments. In other words, the change of energy consumption in high-pollution departments determines the shift in energy consumption of China's industrial sector. It is also concluded that the R\&D subsidy has optimized the energy structure of high-pollution departments through the technical progress and substitution effect. The technical progress is the result of the industrial transformation and upgrading in each department, while the substitution effect means the displacement of traditional coal-based energy with low-price new energies. As a result, high-pollution departments are the main beneficiaries of the R\&D subsidy, and the key to energy conservation and emission reduction in China.

The author put forward the following recommendations according to the research conclusions. First, the high-pollution departments should receive even more R\&D subsidy. The subsidy should be directed at the optimization of the production flow in high-pollution departments, aiming to boost the innovation in production flow and product technologies. This will benefit industrial transformation and upgrading, as well as energy conservation and emission reduction. More R\&D subsidy should be allocated to industries that have successfully upgraded and transformed their technologies, turning them into leaders in industrial transformation and upgrading.

Second, the receivers of the R\&D subsidy should be further clarified. The existing distribution mode of $R \& D$ subsidy must be replaced with one that allocates special funds to key receivers. For high-pollution departments, a group of enterprise with strong technical skills and in good business conditions should be selected to enjoy special funds for technical transformation and upgrading. For enterprises and departments with weak technical skills and in poor business conditions, the R\&D subsidy should be gradually reduced to prevent misappropriation. For low-pollution departments, more R\&D subsidy should be allocated to some key industries to improve the scale and technology of high and new industries.

Third, the technological progress should be further shared between different departments. The spill-over and transformation of technological results are important drivers of energy conservation and emission reduction in China. The government should encourage high and new technology enterprises, especially new energy enterprises, to implement technological transformation, and promote the introduction and application of new energies and new technologies in high-pollution departments. These moves will optimize the energy structure of the entire industrial sector, curb the growth of energy consumption, and suppress pollutant emissions. 
For the future studies, some research issues need to be given further discussion. On one hand, the researchers should pay more attention to the relationship between R\&D subsidy and innovation. R\&D subsidy provides more support for enterprises on technology development because those enterprises would invest more funds in technology development after getting R\&D subsidy. And that, for the measurement of innovation, the researchers should select a new method of measuring innovation instead of patent used in previous articles. On the other hand, the researchers focus not only on innovation but also other approaches of technological progress, such as technological cooperation and technological exchange.

Acknowledgements. The research-launching funding project for introduced high-level talents.

\section{REFERENCES}

[1] Busom, I. (2000): An empirical evaluation of the effects of R\&D subsidies. - Economics of Innovation \& New Technology 9(2): 111-148.

[2] Cohen, W. M., Levinthal, D. A. (2015): Innovation and learning: the two faces of R\&D. Economic Journal 125(583): 546-573.

[3] Danneels, E., Kleinschmidtb, E. J. (2010): Product innovativeness from the firm's perspective: its dimensions and their relation with project selection and performance. Journal of Product Innovation Management 18(6): 357-373.

[4] Guellec, D., Van Pottelsberghe, B. (2003): The impact of public R\&D expenditure on business R\&D. - Economics of Innovation and New Technology 12(3): 225-243.

[5] Han, J., Zheng, Q. L. (2014): How does government intervention lead to regional resource misallocation-decomposition based on intra-industry and inter-industry mismatch. - China's Industrial Economy 11: 69-81.

[6] Jiang, N., Huang, W. (2010): The influence of government subsidies on enterprises' R\&D input based on the empirical research of China's high-tech industry. - Science of Science and Management of S.\& T. 31(7): 28-33.

[7] Lach, S. (2002): Do R\&D subsidies stimulate or displace private R\&D? Evidence from Israel. - Journal of Industrial Economics 50(4): 369-390.

[8] Lichtenberg, F. (2001): The private R\&D investment response to federal design and technical competitions. - American Economic Review 78(3): 550-559.

[9] Lv, Y. W., Sun, H. (2014): Research on the technical efficiency of China's strategic emerging industries and its influencing factors. - Quantitative and Technical Economic Research 1: 128-143.

[10] Maria, C. D., Lange, I., Werf, E. V. D. (2014): Should we be worried about the green paradox? Announcement effects of the Acid Rain Program. - European Economic Review 69: 143-162.

[11] Shang, H. T., Zhu, L. R. (2018): Government environmental subsidies, environmental investment and enterprise environmental performance. Data analysis based on the heterogeneity of property rights of Chinese new energy enterprises. - Ruan Ke Xue 5: 4044.

[12] Sinn, H. W. (2008): Public policies against global warming: a supply side approach. International Tax and Public Finance 15(4): 360-394.

[13] Song, S. L. (2018): Application of gray prediction and linear programming model in economic management. - Mathematical Modelling of Engineering Problems 5(1): 46-50.

[14] Wallsten, S. J. (2000): The effects of government-industry R\&D programs on private R\&D: the case of the Small Business Innovation Research Program. - Rand Journal of Economics 31(1): 82-100. 


$$
-4867 \text { - }
$$

[15] Wu, Q., Liu, B. (2014): Research on the influence mechanism of government R\&D subsidies on innovation in strategic emerging industries. - Industrial Economic Research 6: 41-49.

[16] Xi, J. P. (2017): Win the great victory of building a moderately prosperous society in all respects and building socialism with Chinese characteristics for a new era. Report of the 19th National Congress. - Learning Theory 11: 2-29.

[17] Xiao, W., Lin, G. B. (2014): Government support, R\&D management and technology innovation efficiency based on the empirical analysis of China's industrial sector. Management World 4: 71-80.

[18] Xu, G. Y., Shi, Y., Yang, D. W. (2014): Research on the Policy Promotion Effect of Government R\&D Subsidies. - Ruan Ke Xue 28(9): 30-34.

[19] Zhao, Y., Yao, Y. (2017): Analysis of the dynamic influence of government R\&D subsidies on the R\&D input and output of duopoly based on the perspective of finite rationality. - Scientific Research Management 38(3): 135-143. 